DOI: 10.1515/ausp-2015-0058

\title{
Cultural and Specialized Skills of a Subtitler
}

\author{
Attila IMRE \\ Department of Applied Linguistics, \\ Faculty of Technical and Human Sciences, Târgu Mureş \\ Sapientia Hungarian University of Transylvania \\ attilaimre@ms.sapientia.ro
}

\begin{abstract}
The article offers a practical approach to the skills a present-day translator needs in order to create high-quality translations. Although a lot of theories can be found regarding the skills of a translator, it is worth checking the reality, which is the primary aim of this article. After a short introduction about the standard skills, we look into the subtitling of an episode from a TV series. Our presupposition is that a subtitler has to combine all sorts of information from different fields effectively in order to maintain quality, including general and specific knowledge of the subject matter. Furthermore, the particular environment of subtitling may contain certain pitfalls, such as the technical know-how, layout, and constraints deriving from the nature of subtitling. We can draw the conclusion that a well-prepared translator can successfully handle the technical challenges of multimedia translation of whatsoever type.
\end{abstract}

Keywords: translator's skills, subtitling, legal terms, English, Romanian

\section{Introduction}

We have already expressed our view regarding the expectations concerning translations in the $21^{\text {st }}$ century (Imre 2013: 102, Imre 2014: 251), arguing in favour of translations supported by technology. This technology, revolving around computers, created numerous new jobs, even within the field of translation, having in mind multimedia translators.

Díaz-Cintas discusses the importance of audiovisual translations (AVT) in an article in 2005, stating that "The computer has been one of the advances to have greatly changed the world of translation in general" (2005: 1). He also mentions the large number of "computer programs designed exclusively for subtitling work," but in order to deal with subtitling, we would like to take the 'grand tour' of skills a present-day translator needs to remain competitive on the market of translations. 
We are well aware of the fact that a huge number of books and articles have already discussed the basic skills of a translator, although not being able to define a proper terminology for that. Thus, translators need specific competences, skills, knowledge or ability (cf. SOED definitions in Trumble and Stevenson 2002: 467, 2857) to be successful, and the Directorate-General for Translation (DGT) for the European Commission focuses on three main skills when shaping the translator's profile: language skills, thematic skills, and translation skills, where skills refer to the SOED definition "highly trained or experienced, esp. in a particular accomplishment" (Trumble and Stevenson 2002: 2857).

On the other hand, the European Committee for Standardization (CEN) established the European Standard for Translation Services (EN-15038, 2006), mentioning five competences: translating competence (including specialization and meeting customers' requirements), linguistic and textual competence, cultural competence, technical competence, and research competence, out of which the last one is present during the entire translation process (Durán Muñoz 2012: 79-80).

Others may argue that today we cannot overlook the importance of technical 'know-how' in the translation industry. Quality assurance is directly connected to term bases, translation memories, computer-assisted translation tools in general, and specific translation software as well. In the case of AVT, we should be familiar with various programmes, such as Subtitle Edit, Subtitle Workshop, or Aegisub, to mention but a few, but it is much more than that.

Furthermore, the cultural aspect of translations is rather overshadowed in a mere trident approach (language, thematic, and translation skills) to the issue. As it is not our aim to establish a full list of skills for translators, suffice it to state that the cultural aspects (both similarities and differences) become more and more obvious in this globalized world, and translators not being comfortable with both cultures involved can be easily turned into sitting ducks for the public (cf. the expression 'lost in translation'). No wonder that McKay states: "In-country experience is a big asset for a translator, since translation work involves knowing not just the structure of the language to be translated, but the cultural framework that surrounds it" (McKay 2006: 18), and she adds that "most professional translators have at least some experience working and/or living in a country where their source language or languages are spoken; many translators lived and worked in their source language country for many years". Thus, translators may be well prepared with the necessary language and cultural skills they need during audiovisual translation.

In the following, we will offer an insight into the set of skills a specialized translator - the subtitler - needs in order to produce a good-quality subtitle. 


\section{Subtitling}

Multimedia seem to have fully integrated into our everyday life, capturing our attention in all languages due to - primarily - economic reasons. Nevertheless, the revolution of technology and globalization offered entertainment as well to large masses of people, and today's Hollywood productions pervade our lives with movies and, more recently, with highly popular TV series. ${ }^{1}$

Although there are nations in favour of dubbing - France, Germany, Italy, and Spain (Díaz-Cintas 2003) -, we suspect that there are many people who watch these TV series either online or download full seasons in English with the possibility to add subtitles. According to Szarkowska (2005), subtitling is "the form that alters the source text to the least possible extent and enables the target audience to experience the foreign and be aware of its 'foreignness' at all times". However, foreignness is basically 'Americanism,' as "in Hollywood even God speaks English”, as Nornes mentions (2007: 23) referring to Shohat and Stam's book (1994). The impact of this statement is highly important, if we combine it with Whitman-Linsen's observation:

There is no question that the image Europeans have of America is enormously influenced by motion pictures. What is often overlooked is that it is the dubbing industry handling these films which ultimately does the cultural filtering. Dubbing has the power to represent and misrepresent, distort, sway, and, in general, make a tremendous contribution (positive or negative) to America's image abroad (Whitman-Linsen 1992: 11).

The above statement has become much more noteworthy as the author was only focusing on dubbing, whereas AVT includes subtitling as well, which may be considered as one of the most favoured types of translation (Díaz-Cintas 2003: 195). We now consider multimedia translations as shifting from the so-called "text"-to-betranslated to "whatever"-to-be-translated, such as from the four types of media (TV, radio, printed, and Internet), completed with audiovisual and mobile devices as well. Audiovisual translation may include subtitling, dubbing, voice-over, surtitling, scanlation, fan translation, or (software) localization (Imre 2013: 191-200).

Yet, we should bear in mind the warning: "...nothing is simple when it comes to subtitles; every turn of phrase, every punctuation mark, every decision the translator makes holds implications for the viewing experience of the foreign spectators" (Nornes 2007: 2). At this stage we should only mention two of the formal requirements regarding subtitles, such as the display of no more than 6 seconds (usually at the bottom of the screen), but typically no more than two lines of 35 characters each. These two are already enough to draw the conclusion: "a verbatim rendition is rarely possible" (Imre 2013: 193), and the skills of the subtitler are highly challenged.

1 http://www.imdb.com/search/title?title_type=tv_series, 16.06.2015. 
The challenge may start with the difficulty of the source text, but a rather sobering observation comes from Nornes, who dots the i's this way: "For the time being, spectators will most likely continue to lock away translators in the darkest spaces of the film world, letting them out only to berate them" (2007: 16), reminding us Lambert \& Hermans' remark: there is hardly any feedback between the employer and the translator, unless there is an external complaint (2006: 158). Yet, the translator/subtitler has to be strong enough to deal with that (a possible psychological skill?).

What is worse, these complaints are predominantly related to language and culture, without taking into consideration important guidelines to professional subtitling, such as the Code of good subtitling practice (Carroll and Ivarsson 1998), the BBC's Online subtitling editorial guidelines (Ford Williams 2009), or the ITC guidance on standards for subtitling (1999). Yet, the more we deal with subtitling, the more we realize how many possible hindrances there are for a high-quality subtitle and how much a professional subtitler should know in order not to receive complaints. In the following, we will analyse a Romanian subtitle of a popular TV series (Suits) in 2015, focusing on cultural aspects and legal terminology deriving from the theme of the series.

\section{Cultural skills for Suits}

Díaz-Cintas (2005: 15) states that usually "more importance seems to be given to the actual cultural referent than to a 'correct' translation. The consumer is genuinely interested in the foreign culture and language and the acculturation of terms is avoided." This means that cultural translations are of utmost importance, supported by Kolebáčová, who mentions that "strictly speaking, everything is culture-bound" (2007: 25).

The problem is also amply discussed in Wierzbicka's book, drawing the conclusion that although anything can be expressed in any language, it may be "quite different from one language-culture system to another" (1992: 21). In Newmark's definition, culture is "the way of life and its manifestations that are peculiar to a community that uses a particular language as its means of expression" (Newmark 1988: 94).

When subtitling, the translator is faced with extremely many 'cultural challenges,' which are not so obvious. However, Kolebáčová (2007: 31) offers an insight, mentioning 11 categories (e.g. icons, infrastructure, activities) with many specifications (e.g. famous people, buildings, sports). While watching Suits (S01E01), ${ }^{2}$ a list of nearly 300 entries was created with culture-related or legal terms. Unskilled translators/subtitlers usually have problems with language

2 http://www.imdb.com/title/tt1632701/, 19.04.2015. 
(phraseology, false friends, proverbs, idioms, etc.), abbreviations, acronyms, culture-specific words and expressions (realia), and translating words belonging to slang and taboo.

The last one seems to be a serious issue, as Romanian subtitles tend(ed) to be very prudish, which is hardly compatible with the present-day (American) English used in the movie industry. Judgment over the expressive language may also be subjective, so we may try to comfort ourselves with certain standards of translation, according to which the subtitler - first of all - should retain "a maximum of the original text" (Karamitroglou 1998: 8). The same idea is expressed in the code of subtitling: "All important written information in the images (signs, notices, etc.) should be translated and incorporated wherever possible" (Carroll and Ivarsson 1998: 1). The Editing section of the BBC subtitling editorial guidelines states that viewers should not be deprived "of words/sounds when there is time to include them" (Ford Williams 2009: 4).

As for 'bad' language, the BBC is explicit: "Do not edit out strong language unless it is absolutely impossible to edit elsewhere in the sentence - deaf or hard-of-hearing viewers find this extremely irritating and condescending." Thus, taboo words "should not be censored unless their frequent repetition dictates their reduction for reasons of text economy" (Karamitroglou 1998: 10), and the ITC Guidance gives the verdict: “without censoring” (ITC Guidance on Standards for Subtitling 1999: 4).

We collected thirteen taboo words/expressions in the first episode of Suits, out of which only one translation was explicit (Ro. Mută-ți curul înapoi 'Get your ass in there'); a further one used the official/legal expression for sexual intercourse (Ro. întreține relații sexuale 'to have sex'), and there were two 'standard' established equivalents (Ro. naiba for 'God damn it' and 'hell'). Seven taboo words/expressions were translated with euphemisms (e.g. to have the balls Ro. avea curaj 'to have courage'), and two strong taboo expressions were simply left out in the Romanian version.

The good question is whether this is acceptable or not, taking into account the translators' ethics, the accepted social norms in the $21^{\text {st }}$ century, but one thing is sure: it was a conscious decision of the subtitler going against the previously listed subtitling practices. This means that either the practices rely too much on the English-speaking community standards, or they try to be professional disregarding social norms. On the other hand, the Romanian subtitler follows an unwritten standard, which cannot be called unprofessional. (S)he gives enough proof of knowledge from other type of cultural knowledge, such as clothing (Do you know your inseam? Ro. Ştii ce mărime porți?), playing cards (I'm all in. Ro. Pariez tot.), education (dean Ro. decan) or expressions (make one's bed Ro. 'Ți-ai aşternut patul.). The subtitler even uses a Romanian prison slang (bătrâne 'old women') for the English slang grands 'one thousand dollars'. 
However, certain cultural issues were detected. For instance, a B-student is translated as un student de B minus ('a B minus student'), instead of using the Romanian scoring system (student de nota 6/7). Similarly, if someone gets 1,000 on his/her SATs is not understood, unless we know the maximum $(2,400)$, but the translator preserved the original score (Ro. 1000 la examene), leaving the viewer a little puzzled. Serpico may be understood metaphorically in English, as he was a NYPD officer (Frank Serpico) ${ }^{3}$ and the protagonist of an American movie; yet, the name cannot be preserved in the Romanian translation, as it is not the synonym for a police officer.

We support Karamitroglou's (1998) conclusion that "there is no standard guideline for the transfer of culture-specific linguistic elements," although we do not agree that he only lists five possible alternatives: cultural transfer, transposition, transposition with explanation, neutralization (plain explanation), and omission.

\section{Terminology for Suits}

The importance of terminology is constantly stressed since the advent of CAT-tools, including term bases and translation memories. For instance, the mushrooming of various new jobs/fields of activity and the new meanings of 'old' words lay a considerable stress on professional translators, struggling hard to maintain quality. Thus, general translation is clearly distinguished from the specific one, the latter leading to a specific collection of terms.

Law is a specific field of activity, resulting in thousands of words and expressions with particular meaning, and one should have a thorough knowledge in this area not to commit mistakes with serious consequences (similarly to the medical field).

The importance of legal terminology is also signalled by the numerous dictionaries (mono- and bilingual) published, although sometimes there is no clear distinction between legal and economic terms (the common element may be the financial aspect and the crimes related to it).

Suits is about lawyers and cases, thus we expected the TV series to contain legal terms above the average. We collected more than 170 entries, ranging from common legal terms (deal) to specific ones (to pass the bar) or very specific ones, only understood by experts in the field (Sarbanes-Oxley Act). ${ }^{4}$

The Romanian translator handled the legal terms well, proving talent in proper wording (e.g. paralegal Ro. asistență juridică or the case gets dismissed Ro. cazul este dizolvat). Furthermore, we can observe successful renderings (e.g. fight the

3 http://www.imdb.com/title/tt0070666/, 22.04.2015.

4 http://www.soxlaw.com/s404.htm, 23.05.2015. 
subpoena Ro. somație, hearing on a subpoena Ro. o audiere pentru cererea mea), or good transfer operations, such as broadening (BarBri Legal Handbook Ro. o carte pentru avocați), addition (study for the bar Ro. Am studiat pentru testul de barou), or finding a suitable equivalent (CEO Ro. şef).

The subtitler even differentiates expressions having the same verb in English (make an argument, make somebody come forward), rendering them with construct (Ro. a construi un argument) and make (Ro. să o faci să mărturisească). At a certain point (00:19:40 - 00:21:00), the entire discussion is about law, with fragments from law books with very difficult sentences. Although we can observe a successful word for word translation in this part, due to the limitations of subtitling, the subtitler cannot use explicitation in case of IRC, Section 409A, the Sarbanes-Oxley, or the Sixth Circuit, May 2008. Yet, we can consider the Romanian version successful, as the point here was to prove how good the interlocutors are at law, after which the viewers can accept both of them as experts.

In case the subtitler considers the translation of all the seasons and episodes of Suits (probably at least 80 episodes), creating a term base should be considered as sexual harassment - agresare sexuală, bar - barou, corroborate - confirma, blackmail - şantaj, evidence - probă, etc. will come up in subsequent episodes.

We cannot help not mentioning that here and there the subtitler omitted certain expressions, e.g. grill somebody, affidavit, I object, probably thinking them irrelevant from the point of view of the storyline. After all, it is true that "It will never be possible to apply all of the guidelines all of the time, because in many situations they will be mutually exclusive" (Ford Williams 2009: 3). Thus, overall, we can draw the conclusion that the unknown subtitler did a very good job, even if omitted a basic rule for translators: "The (main) subtitler should be acknowledged at the end of the film or, if the credits are at the beginning, then close to the credit for the script writer" (Carroll and Ivarsson 1998: 2).

\section{Conclusions}

We can state that the bulk of the responsibility lies with the subtitler. Carroll correctly observes that today the subtitler is a translator, technician, and typist as well (2004: 2), and "whoever can offer the lowest rates anywhere in the world has a good chance of getting the contracts" (Gouadec 2007: 286).

In the case of subtitlers, we are still faced with the evergreen problem, namely that the "authorship goes unrecognized" (Nornes 2007: 4), even when this could be easily obtained. For instance, unofficial subtitles - based on the English ones and uploaded by fans without any remuneration - could easily contain the name of the subtitler. However, few subtitles contain the name, although now there is a tendency to offer the nickname and/or an e-mail address of the subtitler. 
It goes without saying that technology "[...] have made life easier for all those working in the world of subtitling," although the work profile is much more ample as "linguistic competence and sociocultural and subject knowledge are no longer sufficient in order to be able to operate effectively in this profession" (Díaz-Cintas 2005: 2). The technical knowledge should be completed with effective research skill/competence, enabling subtitlers "to be conversant with the information and communication technologies" (Díaz-Cintas 2005: 2).

This way we could handle the "growing concern among many professionals" regarding quality assurance in translation/subtitling, but we can also welcome the idea of video player software (e.g. BS Player) to offer the rating of subtitle at the end of the video or when downloading one from the Internet.

Although professional subtitle is supposed to be the result of teamwork, in most cases this means only the subtitler and the proofreader (cf. TED Talks subtitles). We can also agree with Díaz-Cintas (2005: 5) when stating that Ivarsson and Carroll's (1998) attempts of a code of good subtitling practice were not very successful.

Our analysis shows that a subtitler is a forever learner in the field of culture, translation, and language, but we should add further areas as well, such as the ever-demanding technical skills, research skills, self-management skills (in negotiation and finances), and even psychological skills that strengthen the translator/subtitler in the ups and downs.

Finally, we can take the necessary preventive measures if we remember "Subtitling conventions are not set in stone." (Díaz-Cintas 2005: 16) and, whatever the case, the proper knowledge of the source and target language will always prevail.

\section{Acknowledgement}

The research presented in this paper was supported by the European Social Fund under the responsibility of the Managing Authority for the Sectoral Operational Programme for Human Resources Development (Sistem integrat de îmbunătățire a calității cercetării doctorale şi postdoctorale din România şi de promovare a rolului ştiinței în societate), as part of the grant POSDRU/159/1.5/S/133652.

\section{References}

Carroll, Mary. 2004. Subtitling: changing standards for new media? The LISA Newsletter Globalization Insider XIII(3.3). http://www.translationdirectory. com/article422.htm. 
Carroll, Mary-Jan, Ivarsson. 1998. Code of good subtitling practice. European Association for Studies in Screen Translation. http://www.transedit.se/code. htm.

Díaz-Cintas, Jorge. 2003. Audiovisual translation in the third millennium. In: Translation today: trends and perspectives. pp. 192-204.

Durán Muñoz, Isabel. 2012. Meeting translators' needs: translation-oriented terminological management and applications. The Journal of Specialised Translation (18): 77-92.

Ford Williams, Gareth (ed.). 2009. BBC's Online subtitling editorial guidelines V1.1. BBC. http://www.bbc.co.uk/guidelines/futuremedia/accessibility/ subtitling_guides/online_sub_editorial_guidelines_vs1_1.pdf.

Gouadec, Daniel. 2007. Translation as a profession. N20.30.06. x, John Benjamins Publishing.

Imre, Attila. 2013. Traps of translation. Braşov: Editura Universității "Transilvania."

2014. How (not) to fail as a multimedia translator. Acta Universitatis Sapientiae Philologica 6(2). Studies on Linguistics: 249-259.

Karamitroglou, Fotios. 1998. A proposed set of subtitling standards in Europe. Translation Journal 2(2). http://www.bokorlang.com/journal/04stndrd.htm.

Kolebáčová, Radka. 2007. Culture-bound issues in subtitling: a comparative study of films for adult vs. young audiences. MA Thesis, Masaryk University.

Lambert, José-Johan Hermans. 2006. From translation markets to language management: the implications of translation services (1998). In: Functional approaches to culture and translation. Amsterdam / Philadelphia: John Benjamins Publishing Company. pp. 147-162.

McKay, Corinne. 2006. How to succeed as a freelance translator. Lulu.com.

Newmark, Peter. 1988. A textbook of translation. Prentice-Hall International.

Nornes, Markus. 2007. Cinema Babel: translating global cinema. Minneapolis: University of Minnesota Press.

Shohat, Ella-Stam, Robert.1994. Unthinking Eurocentrism: multiculturalism and the media. London-New York: Routledge.

Szarkowska, Agnieszka. 2005. The power of film translation. JoSTrans: The Journal of Specialised Translation 9(2). http://accurapid.com/journal/32film. htm.

Trumble, William R.-Angus Stevenson (eds). 2002. The shorter Oxford English dictionary, vol. II. $5^{\text {th }}$ edition. Oxford: Oxford University Press.

Whitman-Linsen, Candance. 1992. Through the dubbing glass, vol. 251. AngloSaxon Language and Literature. European University Studies 14. Frankfurt/M., Berlin, Bern, New York, Paris, Wien: Peter Lang.

Wierzbicka, Anna. 1992. Semantics, culture, and cognition. Oxford University Press. 
XXX. Multilingual matters. 2005. Back to the Future in Subtitling. In: MuTra2005. pp. 1-17. http://www.euroconferences.info/proceedings/2005 Proceedings/2005_proceedings.html. XXX. ITC guidance on standards for subtitling. 1999. ITC. www.ofcom.org.uk/.../ itc/.../ITC_Guidance_on_Standar...

\section{Online sources}

http://www.imdb.com/search/title?title_type=tv_series, 16.06.2015.

http://www.imdb.com/title/tt1632701/, 19.04.2015.

http://www.imdb.com/title/tt0070666/, 22.04.2015.

http://www.soxlaw.com/s404.htm, 23.05.2015. 